\title{
Application of Halalan Tayyiban in the Standard Reference for Determining Malaysian Halal Food
}

\author{
Sazelin Arif ${ }^{1} \&$ Safiah Sidek $^{1}$ \\ ${ }^{1}$ Centre for Languages and Human Development, Universiti Teknikal Malaysia Melaka, Malaysia \\ Correspondence: Sazelin Arif, Centre for Languages and Human Development, Universiti Teknikal Malaysia \\ Melaka, Hang Tuah Jaya, 76100 Durian Tunggal, Melaka, Malaysia. Tel: 606-331-6924. E-mail: \\ sazelin@utem.edu.my
}

Received: January 16, 2015 Accepted: January 28, 2015 Online Published: June 5, 2015

doi:10.5539/ass.v11n17p116 URL: http://dx.doi.org/10.5539/ass.v11n17p116

\begin{abstract}
The increase number of cases on the misuse of halal logo and questionable status of halal food has raised many concerns among the Muslim consumers regarding the status of halal food in Malaysia. The various reports on the issues of fraud in halal food also indicate that there are weaknesses in the procedure of determining halal food. In this case, an investigation on the procedures and standard reference used by the Department of Islamic Development Malaysia (JAKIM) to determine halal food in Malaysia needs to be conducted in order to gain the consumer's trust and confidence on JAKIM's logo. This study advocates that the concept of halalan tayyiban should be used as the framework to determine halal products as it considers both the physical and spiritual benefits of the food to mankind. So far, it has not been proven that the standard references used by JAKIM are consistent with this concept. Specifically, this study aimed to investigate the application of halalan tayyiban in the standards and procedures used by JAKIM to determine halal food in Malaysia. For this purpose, a framework for determining halal food based on the concept of halalan tayyiban has been developed. Four main standard references used by JAKIM, namely the Malaysian Standard MS 1500, MS 1480, MS 1514, Halal Food Manual Procedures, Food Acts 1983 and Food Regulations 1985 were then analysed based on the developed framework. Additionallly, semi-structured interviews were conducted with selected key personnel from JAKIM to verify the application of halalan tayyiban in the procedure of issuing halal food certification. This study revealed that the standard references used by JAKIM were consistent with the concept of halalan tayyiban. The practice taken by JAKIM's personnel to issue the halal food certification also conformed to the concept of halalan tayyiban. It can be concluded that JAKIM has applied the concept of halalan tayyiban in determining halal food in Malaysia. These findings help to improve the consumers' confidence on the food determined as halal by JAKIM. They also contribute to development of the well-being and sustainability of a community, especially the Muslim community.
\end{abstract}

Keywords: halalan tayyiban, halal food certification, Malaysian standards

\section{Introduction}

\subsection{Background of the Study}

Islam has outlined specific guidelines for its people when making decision on which food and drink to be consumed. In general, foods identified as halal are permissible to be consumed, whereas foods identified as haram should be avoided by the Muslims. The guidelines to determine halal food are based on the concept of halal and goodness (tayyib) which refers to clean, pure, safe, harmless and high quality (al-Qurtubi, n. d.; al-Tabari, n. d.; al-Suyuti, 1990; Ibn 'Ashur, 1984). In al-Quran, the term halal is frequently expressed by the term al-tayyib or al-tayyibat, as stated in surah al-Baqarah (2) verse 168, surah al-Ma'idah (5) verse 88, surah al-Anfal (8) verse 69 and surah al-Nahl (16) verse 114. These verses clearly explain that any food considered halal must conform to the conditions expressed in the meaning of halal and tayyib (Sharifah Zannierah et al., 2012).

Halal food in Malaysia is determined based on the issuance of halal certificate by the Department of Islamic Development Malaysia (JAKIM). Generally, JAKIM is entrusted with the responsibility to issue of the halal status for local products, foreign manufacturing and processing plants intending to export their halal products to Malaysia. Besides JAKIM, the State Islamic Religious Department (JAIN) and State Islamic Religious Council 
(MAIN) are given the authority to issue the halal certificates for domestic market (JAKIM, 2012). The issuance of halal food certificate involves several procedures performed by the syariah and technical auditors from JAKIM. According to JAKIM (2012), the responsibility to determine the halal status of the products involved not only on the official site inspection of plants, but also the examination on how the halal status of the raw material is maintained and monitored at all times. It also requires the appointment of reputable and reliable foreign halal certification bodies or organizations to monitor the halal status of the raw materials since many raw material used in local food productions are imported products. In this case, JAKIM needs to have a standard procedure that provides a complete guide for the food operators to produce a safe and halal food.

In relation to the development of technology in the food industry and the ease of people's mobility across the globe, food have undergone various processes, leading to difficulties to differentiate between halal and haram food. Further, with the increase number of non-Muslims dominating the food industry, the status of halal food has become doubtful. In this respect, many cases of questionable halal food have been reported in the mass media recently. For example, the halal issue of Cadbury chocolates, namely the Cadbury Dairy Milk Hazelnut and the Cadbury Dairy Milk Roast Almond. It has been been reported that these chocolates have pig's DNA (Utusan Malaysia, 24 May 2014), which was later disclaimed by JAKIM (Sinar Harian, 2 June 2014). Additionally, issues of the various food factories that do not comply to the Food Acts and Food Regulations have always raised concerns among the Muslim consumers. Among them are food exposed to microbiology, dyes, and flavour. The excessive use of preservatives, such as boric acid and benzoic acid are still prevalent in the manufacturing of yellow noodles, fishballs, fishcakes and flat sphagetti (Saifol, 2011). Another case related to doubtful halal product reported by the mass media is the use of halal logo. Some examples are the discovery of a dirty bread factory that uses halal logo (http://:www.muslimconsumer.org.my), the use of halal logo on food produced from unslaughtered chicken (Berita Harian, 20 February 2008) and many others. Hidden ingredients from various sources present another serious problem for Muslim consumers (Riaz \& Chaudry, 2003). The various reports on the issues of fraud in the halal food industry shows that there are some weaknesses in the procedure to determine halal food.

The instances mentioned above have led to an increasing concern on the quality and safety of the food produced in the market which may affect the consumers' confidence in consuming these foods. It seems that the food manufacturers do not seriously comply with the safety procedures during the preparation of the food. People are beginning to question the standards and procedures used by JAKIM in determining halal food. Further, the tendency of some food operators that manipulate the JAKIM halal logo for the sake of maximising their profit has become a serious issue that needs to be tackled. This incidence has also affected people's trust and confidence on JAKIM's halal logo.

\subsection{Objectives of the Study}

This study aimed to investigate whether JAKIM fully applies the concept of halalan tayyiban in the standard reference of halal food. Specifically, the research questions that this study aimed to address are:

- What are the procedures adopted by JAKIM to determine halal food in Malaysia?

- To what extent does the standard reference used by JAKIM to determine halal food in Malaysia apply the concept of halalan tayyiban?

This paper reports on a study that investigated the procedures used by JAKIM to determining halal food in Malaysia and the application of the concept halalan tayyiban in the standard references they use to determine halal food in Malaysia. To achieve this purpose, this paper is divided into five main sections. Besides the introduction as the first section, the second section describes the concept of halalan tayyiban and other relevant concepts which were used as the basis to develop a halalan tayyiban-based framework for determining halal food. The third section describes the methodology of this study, while the fourth section presents the findings and discussion. This paper ends with the conclusion as the final section.

\section{Literature Review}

\subsection{The Concept of Halalan Tayyiban}

A literature review related to the concept of halalan tayyiban is essential for the formulation of the basic framework for determining halal food in Malaysia. To get a clear understanding of this concept, the discussion in this section focuses on the two basic words, namely halal and haram that form the concept of halalan tayyiban.

The word halal is originated from the Arabic word, حل، يحل، حلا which means to set free, to let go, to dissolve and to allow or to exit from something that is illegal (haram) (Ibn Manzur, n. d). Linguistically, halal is defined 
as something that should be allowed and cannot be punished if it is conducted (Sa'id Abu Jayyib, 1998). It is defined as permitted, allowed, lawful and legal (Mohammad, 1993). In short, it means anything that is not prohibited and it is lawful, particularly food and meat from animals that have been ritually slaughtered (Cyril, 1989).

Haram is the antonym of halal (Ibn Manzur, n. d.). It is originated from the Arabic word حرم، يحرم، حرما، حر اما (Mوأ This word can be understood as prohibited, forbidden, unlawful, restricted and unpermitted (Mohammad, 1993). Islamic scholars define haram as something that should be avoided by the Muslims, and committing the act of haram is sinful and immoral (Ibn Hazm, 1983). The word haram also refers to anything that must be avoided as stipulated in the rule of Islam. It is believed that any Muslims who commit to this act will receive punishment in the hereafter, and sometimes they may receive the punishment in the present world (al-Zuhayli, 1969).

There are specific commands from Allah s.w.t. regarding the selection of halal food, particularly related to the term al-tayyib or al-tayyibat. Allah s.w.t. commands His people to eat halal and good quality food, while at the same time avoid taking filthy food. The term al-tayyibat is orginated from the word taba which means good, tasty, delicious, sweet, pure, clean, and uncontaminated by things that are makruh (Ibn Manzur, n.d; al-Ghazzali, n.d). The command to select halal food and tayyib is available in several verses of the al-Quran, and one of them is surah al-A'raf (7) verse 157. In this verse, the word al-tayyibat is interpreted as halal (al-Qurtubi, n. d.; al-Tabari, n. d.; al-Suyuti, 1990), halal and not repugnent (Ibn 'Ashur, 1984). Another definition is halal, good, beneficial to the body and helpful in terms of habits and the law of Islam (Ibn Kathir, n. d.).

The word tayyib is also mentioned in surah al-Baqarah (2) verse 168. In this verse, al-Sharbini (n.d) claimed that the word tayyiban has four main elements:

i- $\quad$ The content of the food is from the source that is halal, not haram;

ii- $\quad$ The food is clean and does not have any kind of impurities;

iii- The food does not cause any pain or misery to the people who consume it; and

iv- The food consists of elements that are nutritious and beneficial to the people who consume it.

In this regard, Sazelin \& Ridzwan (2011) suggested for the need to combine the concept of tayyib and halal. This suggestion is consistent with the understanding of Islamic scholars, such as al-Qurtubi, al-Suyuti, Ibn 'Ashur and Ibn Kathir. It is also based on the command from Allah s.w.t. that mankind should choose foods that have the features of halalan tayyiban.

The concept of halalan tayyiban considers all the physical and spiritual advantages of the food to the humankind. In this regard, halalan tayyiban can be interpreted as foods that are permitted to be consumed (halal) and can give benefits to the human body. In other words, food that is classified as halalan tayyiban is the food that fulfills the two criteria: firstly, the food is halal and taken from a halal source, and secondly, the food is a quality food as it provides benefit for those who consume it. Food that does not have these two criteria is not classified as halalan tayyiban, hence it should be avoided.

The application of the concept of halalan tayyiban indicates that the determination of halal food encompases both the tangible and intangible aspects of the food: The food identified as halal must be in good quality, hygiene and safe to be consumed. Further, this concept is applicable from the initial preparation of the food until its final production. This includes the process of preparation, manufacturing and distribution of the food until it is served to the customers. The concept of tayyiban does not mean that the food must be halal, good, delicious, tasty and pure only. It also means that the food must be beneficial to the body and does not cause any harm. Further, what is beneficial for the body is also beneficial for the human's mind and soul (al-Ghazzali, n.d). Further, Sazelin \& Ridzwan (2011) stated that the good quality food bounded by Islam has a strong relationship in developing good quality human capital.

Clearly, the selection of food based on the concept of halalan tayyiban outlines that a halal food does not necessarily mean that they are free from illegal raw material, such as pig or unslaugthered livestock. Halal and tayyib foods should be viewed from the aspect of its complete supply chain starting form the farm to the dinner table which includes the food processing and preparation, ingredients and cleanliness. Throughout the process, it is important to ensure that the food does not contain any illegal substances or it is contaminated by harmful products which may be harmful to the human's life and health.

\subsection{Principles of Determining Halal Food Based on the Concept of Halalan Tayyiban}

The principles of halal and haram need to be considered when developing a framework to determine halal food. al-Qaradawi (1989) has outlined several general principles to differentiate between halal and haram. These 
principles, which are outlined below provide a general guideline when dealing with issues of halal, not inclusive to halal food only:

i. The basic asl (origin) is that all things created by Allah are halal, with few exceptions that they are prohibited (haram).

ii. To make things lawful and to prohibit things is the right of Allah alone. No human being, no matter how pious or powerful may take this right into his/her own hands.

iii. Prohibiting the halal and permitting the haram is similar to committing a Shirk (ascribing partners to God).

iv. The basic reasons to prohibit things are due to their impurity and harmfulness. A Muslim is not required to know exactly why or how something is unclean or harmful in what Allah has prohibited. There might be obvious as well as obscure reasons.

v. What is halal is sufficient, what is haram is superfluous. Allah prohibits only things that are unnecessary while providing better alternatives.

vi. Whatever is conducive to haram is itself haram. If something is haram (prohibited), anything leading to it is also haram.

vii. Falsely representing the haram as halal is prohibited. Representing lawful as unlawful is also haram.

viii. Good intentions do not make the haram acceptable. In the case of haram, it remains haram no matter how good the intention or how honorable the purpose is.

ix. Doubtful things are to be avoided.

$\mathrm{x}$. The haram is prohibited to everyone alike. Islamic laws are universally applicable to all races, creeds and sexes.

xi. Necessity dictates exceptions.

Based on the concept of halalan tayyiban and the general principles above, a framework to determine halal food has been formulated. The framework takes into consideration both the physical and spiritual aspects of the food, which are derived from the concept of halalan tayyiban. It will be used as a benchmark to make comparison to the standard reference of halal food adopted by JAKIM. This framework is presented in Table 2 in the findings and discussion section.

\section{Research Methodology}

\subsection{Research Design}

This study aimed to investigate the application of halalan tayyiban in determining halal food by JAKIM. To achieve this aim, the study was designed based on three research approaches. Firstly, a literature review was conducted to formulate a framework that determines halal food based on the concept of halalan tayyiban. This framework was drawn from the authorised scriptures related to this area. Further, following the Islamic approach of seeking knowledge, four main source of references have been utilised, which are the al-Quran, hadis, ijmac and qiyas. The second approach is document analysis. Based on the formulated framework, document analysis was conducted to determine the application of the halal and tayyib concept in the halal food certification standards. Four documents were analysed, which are the Malaysian Standard MS 1500 (2009), MS 1480 (2007), MS 1514 (2009), Manual Procedure of Halal Certification Malaysia (2005) and Food Acts 1983 and Food Regulations 1985 (2007). These documents are the standards, guidelines and control act imposed by the Malaysian government on activities related to food preparation in Malaysia.

Finally, semi-structured interviews were conducted in order to verify the actual application of halal and tayyib concept in the standards. For this purpose, the interviews were conducted with the experts who have been given the authority by the Malaysian government in halal food certification process. The respondents were selected from the shariah auditors and technical auditors responsible for the issuance of halal food certification. They were from the Department of Halal Hub JAKIM. The selection of the respondents was based on a non-randomized sampling. The interviewed respondents were also requested to suggest suitable candidates to be interviewed. Open-ended questions, such as how, what, when, where, and why were used in this study. This allows the respondents to have the comfort and confidence in giving their responses using their own words.

\subsection{Data Analysis}

The data were analysed based on two main approaches, namely the deductive and inductive approach. For the inductive approach, the data were analysed for the purpose of finding evidence and explanation from specific 
issues related to halal food and the concept of halalan tayyiban. The deductive approach involves an analysis of the data to explain the application of the concept of halalan tayyiban in the standard reference of the halal food. Besides, a comparative approach was used to compare and sort the data by highlighted the differences and similarities between the formulated theoretical concept and the standard reference used to determine Malaysian halal food.

\section{Findings and Discussion}

\subsection{Standards and Procedure to Determine Halal Food}

The procedures adopted by JAKIM to determine halal food are based on relevant standards, manual procedures and acts related to halal food, which are published by several bodies in Malaysia, such as the JAKIM itself, Department of Standards Malaysia, Institute of Islamic Understanding Malaysia and Malaysian Institute of Industrial Research and Standard (SIRIM). These standards are used as guidance by JAKIM when issuing the halal food certificate.

i- Malaysian Standard MS 1500:2009 Halal Food - Production, Preparation, Handling and Storage General Guidelines (Second Revision);

ii- Malaysian Standard MS 1514 :2009 Good Manufacturing Practice (GMP) For Food (First Revison);

iii- Malaysian Standard MS 1480:2007 Food Safety According to Hazard Analysis and Critical Control Point (HACCP) System (First Revison);

iv- Manual Procedure of Halal Certification Malaysia; and

v- Food Acts 1983 and Food Regulations 1985

Malaysian halal food standard MS 1500 which was revised in 2004 and 2009 is proven to be the widely accepted standard by the Organization of Islamic Countries (OIC). This is due to the fact that Malaysia is a Muslim country which practices the standard of halal in a very strict manner, and has been cited as the best example in the world in terms of justifications of halal food by the United Nations (Zulkifli, 2007; Winai \& Jongjit, 2006). This standard prescribes practical guidelines to prepare and handle halal food starting from the selection of raw materials until its distribution and marketing activities for the food industries. It has become the basic requirement for food production process in Malaysia (Zakiah et al., 2014). It involves specific procedures for slaughtering, processing and other related operations as prescribed by the Islamic law. It also certifies raw materials, ingredients and products based on quality, sanitary and safety considerations and serves as a basic requirement for food products and food trade or business in Malaysia (MS 1500, 2009; Lokman, 2005).

To strengthen its application, the standard MS1500 should be used together with other standards related to food, such as the MS 1480 Food Safety and MS 1514 Good Manufacturing Practice. Both the Malaysian Standard MS 1480 and MS 1514 Good Manufacturing Practices (GMP) describe the requirement for food safety during its preparation, processing, manufacturing, packaging, storage, transportation, distribution, handling or offering for sale or supply in any sector of the food chain (MS 1480, 2007). The MS 1514, on the other hand, focuses on the food chain from the incoming materials to the customer. Hence, it is necessary to set hygiene conditions for producing food, which is safe and suitable for consumption in the food manufacturing (MS 1514, 2009). In terms of its application, both standards should complement each other, while at the same time they also must refer to Food Acts 1983 and Food Regulations 1985.

The Manual Procedure of Halal Certification Malaysia was published by JAKIM in 2005. It is a complementary document to MS 1500, MS 1514 and MS 1480. This manual covers the application procedure, inspection, monitoring and enforcement of halal food. It is used as guidelines to co-ordinate the implementation of halal certification activities in Malaysia at JAKIM's federal level and states and provides the basic principles to be adopted by every halal certificate holder in Malaysia. The issuance of halal certificate is only made upon the applicant's compliance to all standards listed and requirements in the manual (JAKIM, 2005).

In Malaysia, the process of halal food certification begins when the manufacturers or food industries submit their application to JAKIM. The applicants need to provide the details of ingredients, name/s and address of manufacturer/s or supplier/s of ingredients, original halal status of ingredients such as the halal certificate from the recognized Islamic bodies or product specification, manufacturing processes and procedures, such as HACCP and GMP (Mohd Amri, 2008; Sazly, 2008). To receive the halal food certification, applicants must comply with all the guidelines underlined in halal food standard, GMP standard, HACCP standards as well as the manual. Besides undergoing interviews conducted by the shariah auditors and technical auditors from the Department of Halal Hub JAKIM, applicants may also need to refer to the following five main agencies 
involved in halal food certification process. These agencies, led by JAKIM are listed according to their functions in Table 1.

Table 1. Related agencies and their functions

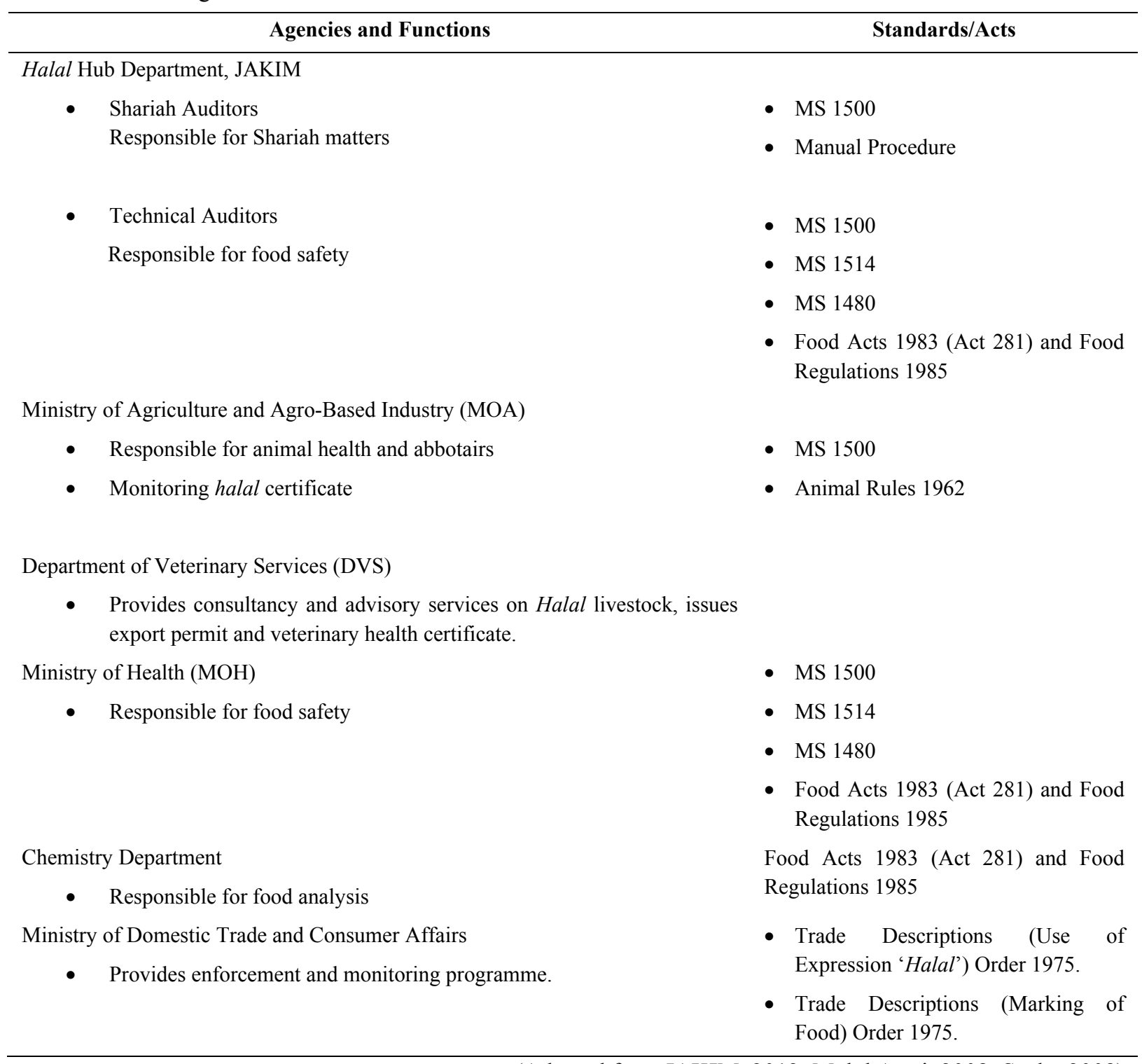

(Adapted from JAKIM, 2012; Mohd Amri, 2008; Sazly, 2008)

\subsection{The Application of Halalan Tayyiban in the Standard Reference for Determining Malaysian Halal Food}

A framework to determine the application of concept of halalan tayyiban in the standards and practice used by JAKIM to determine halal food has been developed. As mentioned earlier, this framework is underpinned by the two criteria underpinning the concept of halalan tayyiban, which are the halalness of the food and the benefits of the food to mankind which emphasises the aspect of quality, safety and health. Figure 2 outlines eight criteria for determining halal food based on the general principles discussed by al-Qaradawi (1989).

These criteria as outlined in Table 2 are used as a benchmark to make comparison to the standard reference used by JAKIM in determining halal food. To facilitate the analysis, these criteria were labelled based on specific acronyms, ranging from HL 1 to HL 8. Table 3 shows the mapping of the eight criteria to the respective aspects of the standards used by JAKIM to determine halal food. 
Table 2. Framework for Determining Halal Food based on the Concept of Halalan Tayyiban

\begin{tabular}{|c|c|}
\hline Methods & Acronym \\
\hline $\begin{array}{l}\text { There is no prohibition on the food from the Quran or any source of Islam regulations based on the principle } \\
\text { that the food is orignally halal and pure until a holy statement states that the food is haram. }\end{array}$ & HL 1 \\
\hline The original ruling of a specific food that can be harmful to human is haram. & HL 2 \\
\hline $\begin{array}{l}\text { Halal food must be able to preserve human's life and health, and any food that hinders this potential is } \\
\text { considered haram. }\end{array}$ & HL 3 \\
\hline People have confidence without any doubt on the halalness of the food labelled as halal. & HL 4 \\
\hline Halal food must not contain any parts of livestock that are haram or considered filthly. & HL 5 \\
\hline Halal food must be slaughtered based on the Islamic law. & HL 6 \\
\hline Halal food must be clean and pure throughout the chain of its manufacturing process. & HL 7 \\
\hline $\begin{array}{l}\text { Halal food emphasizes elements of blessings. Therefore, Muslims must take part in the process of preparing } \\
\text { the food. }\end{array}$ & HL 8 \\
\hline
\end{tabular}

Table 3. Application of Halalan Tayyiban in the Standard Reference to Determine Halal Food in Malaysia

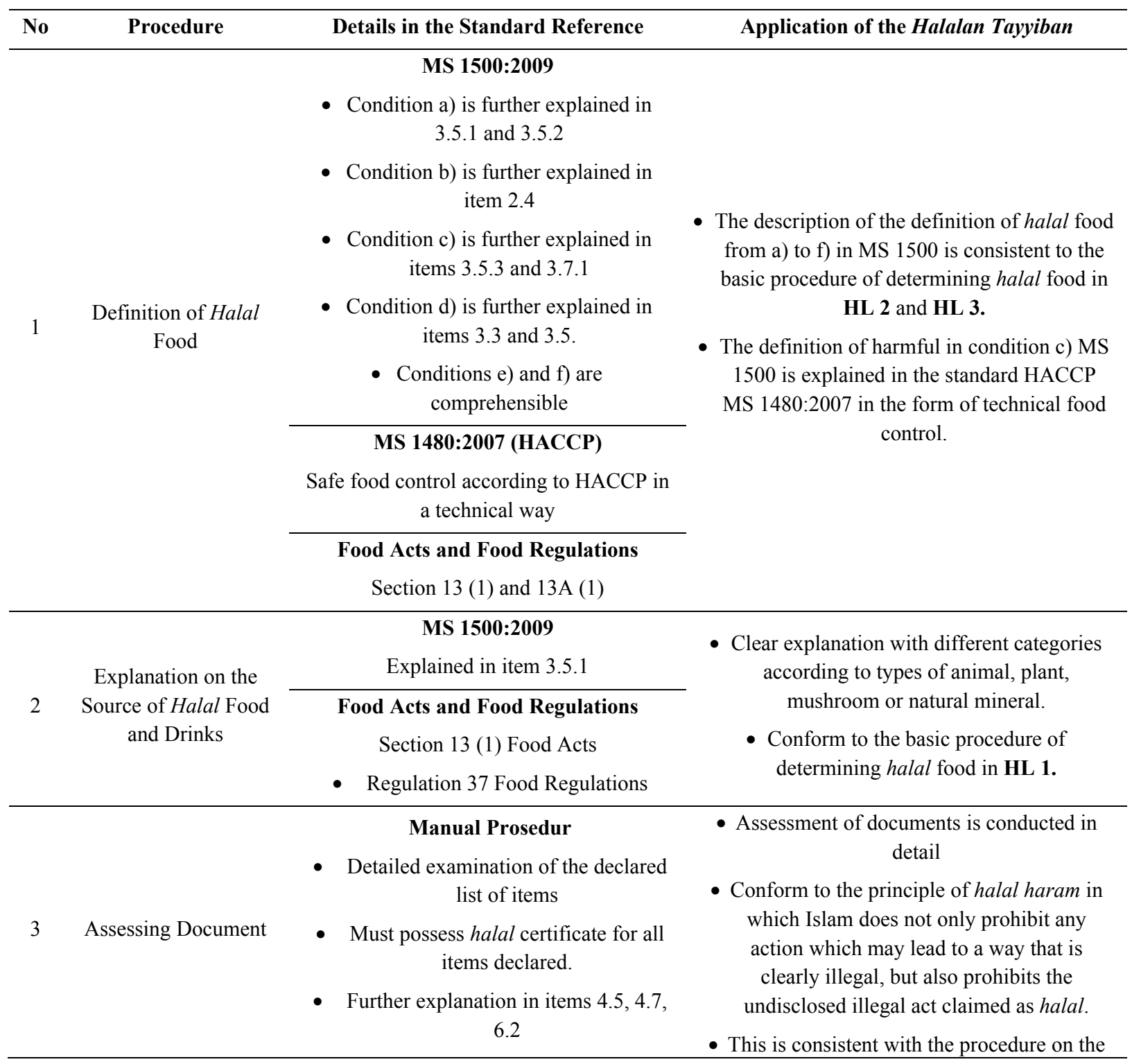


determining of halal food in HL 4 and HL 5.

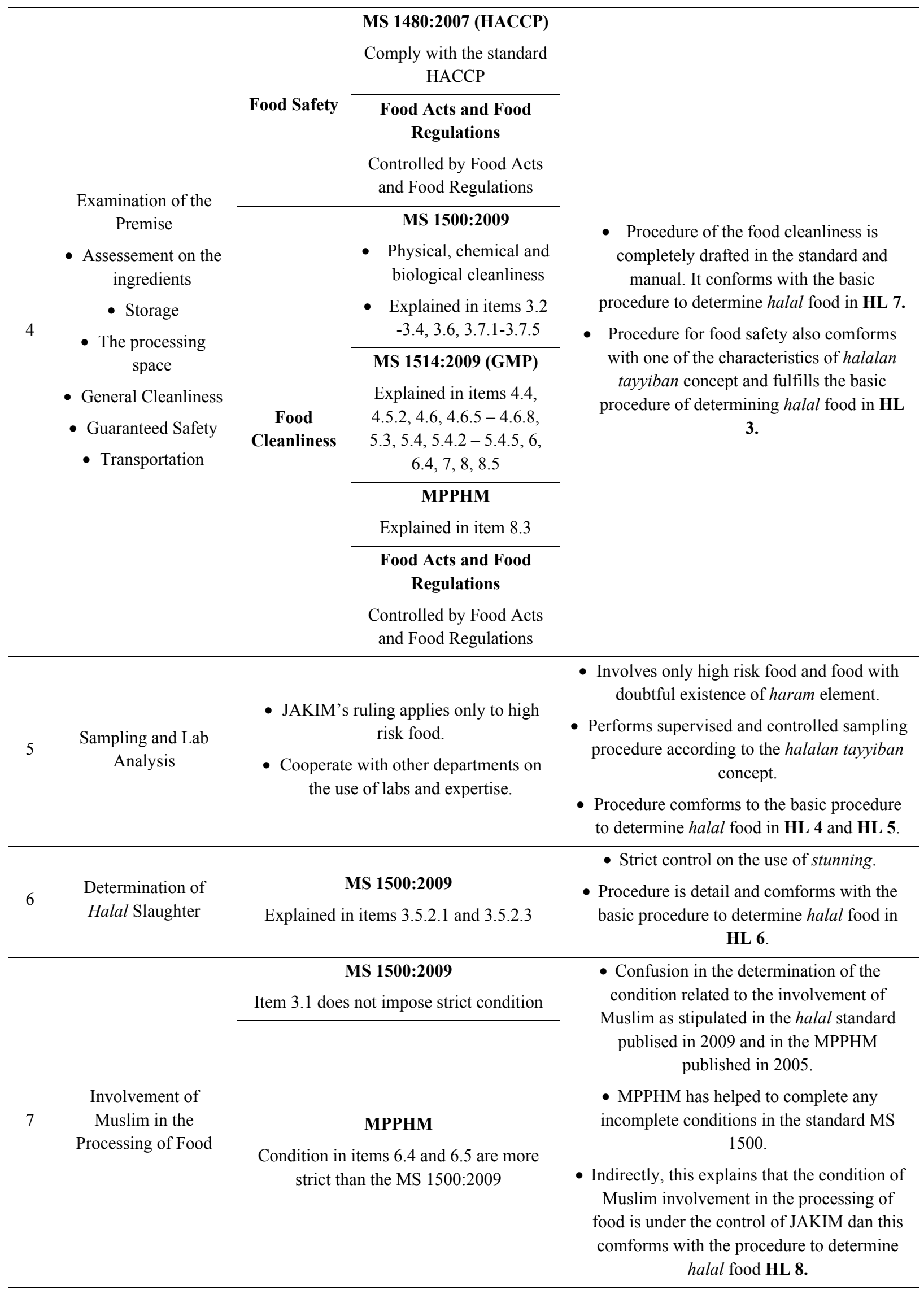


The combination of the four standards used by JAKIM shows evidence that the concept of halalan tayyiban has been applied when determining halal food in Malaysia. Further explanation of the application of halalan tayyiban in the seven aspects of standards for determining halal food is presented in the following section.

\subsubsection{Definition of halal Food}

The definiton of halal food is specifically described in the standard MS 1500. It states that halal food must fulfill the following conditions (MS 1500, 2009):

i- The food or its ingredients are not filthy (najs) according to Syariah law

ii- The food does not contain any ingredients that are filthy (najs) according to Syariah law

iii- The food is safe and not harmful

iv- The food is not prepared, or manufactured using equipment that is contaminated with things that are filthy (najs) according to Syariah law

v- The food or its ingredients does not contain any human parts or its derivatives that are not permitted by Syariah law

vi- During its preparation, processing, packaging, storage or transportation, the food is physically separated from any other foods that do not meet the requirements stated in the above items (i-v) or any other things that have been decreed as filthy (najs) by Syariah law.

The condition for no iii), is further explained in item 3.5.3 in the standard MS 1500, whereby the process of handling, distribution and serving halal food must comply with the condition that the food or its related processed ingredients should be safe for consumption, not poisonous, not intoxicated or detrimental to human's health. Similarly, the explanation of the packaging, labeling and advertisement in item 3.7.1 in the standard MS 1500 specifies the condition that the packaging material must not have any toxic effect on the halal food. This is to prevent harmful effect on the halal food due to the exposure of toxic.

The definition of halal that is, it must be safe for consumption, non-toxic, non-intoxicated or non-detrimental to health is further described in the standard MS 1480: 2007. This standard describes the necessary requirements to ensure that the food security is in accordance with the Hazard Analysis Critical Control Point (HACCP) in terms of preparing, processing, manufacturing, packaging, storage, transportation, distribution and handling. The definition of halal food in this standard is also subjected by the Food Acts 1983 and Food Regulations 1985. The Food Acts 1983 Section 13 (1) and section 13A (1) impose a control on the food manufactured or sold identified as unsafe for consumption, toxicated and harmful to health. In general, the descriptions of the definition of halal food from outlined in the MS 1500 conform to criteria HL 2 [The original ruling of a specific food that can be harmful to human is haram ] and HL 3 [Halal food must be able to preserve human's life and health, and any food that hinders this potential is considered haram].

\subsubsection{The Source of Halal Foods and Drinks}

The standard halal MS 1500: 2009 3.5.1 explains in detail the sources of halal food and drink. This description is divided into several categories, namely animals, plants, fungi and micro-organisms, natural minerals, chemicals and drinks. Animals are further divided into two categories, which are the land and aquatic animals. The types of land and aquatic animals are clearly explained in items 3.5.1.1.1 and 3.5.1.1.2 in MS 1500. Further, item 3.5.1.7 in the standard MS 1500 states that dangerous aquatic animal or plant can be halal if the toxin or poison from the plants and animals have been discarded during the food processing as permitted by the Islamic law.

The control on the source of foods and drinks in halal food in the standard MS 1500: 2009 is also subjected to the Food Acts 1983 and Food Regulations 1985, when there is a case of misuse. This is clearly stated in Section 13 (1), the Food Acts 1983 and Rule 37, 1985 and it is in line with criteria HL 1 [There is no prohibition on the food from the Quran or any source of Islam regulations because the original regulation is that the food is halal and pure until a holy statement states that the food is haram].

\subsubsection{Evaluating the Documents}

Before issuing the halal food certificate, an evaluation of the documents submitted by the applicants is conducted. The evaluation involves examining the source of origin of the raw materials declared by the applicant. In this case, the applicant has to provide a detailed list of the source and ingredients of each of the food applied for the halal status. The auditor categorises the source of raw materials into two categories: 1) plant-based products, and 2) animal-based products. For products derived from plants, the source needs to be examined and 
analyzed whether they are poisonous or otherwise. For products derived from animal, the way the animals is slaughtered and their food intake need to be carefully analysed. Further, the ingredients and other added raw materials need to be carefully examined to ensure that they do not have filthy substances (Sazly, 2008; Mohd Amri, 2008). This requirement is explained in the Manual Procedure of Halal Certification Malaysia (2005) in items $4.5,4.7$, and 6.2 .

During the detailed examination of the documents, the auditor will request the applicants to secure halal certification for each of the raw material and ingredient declared as the content of the food. Applicants also have to provide evidence the body issued the halal certificate is recognised by JAKIM. This requirement applies for any related material that has halal certificate issued by a body from outside Malaysia, including the halal certificate from the abattoirs. For materials that are questionable or have unknown content specifications, applicants are required to submit samples of these materials to any accredited chemical laboratory, and then send the specification to JAKIM. There are also cases where JAKIM'S auditors themselves send the questionable product samples to the laboratory for analysis. For any seafood products that require halal certification, the materials used must be translated into Malay or English, certified from the National Institute of Translation (Sazly, 2008; Mohd Amri, 2008).

The examination of the document is conducted very carefully and in detail. It is consistent with the principles of halal haram that Islam does not only prohibit any act which may lead to a way that is clearly illegal, but also any illegal act claimed to be halal. This practice is also consistent with the criteria HL 4 [People have confidence without any doubt on the halalness of the food labelled as halal], and HL 5 [Halal foods must not contain any parts of livestock that are haram or considered filthy].

\subsubsection{Examining the Premises for Safety and Cleanliness}

The purpose of examining and inspecting the premises/factory is to evaluate the level of food safety and cleanliness. The inspection is usually conducted by both the syariah and technical auditors. For this purpose, JAKIM's auditors use two standards, namely the Good Manufacturing Practice standard MS 1514: 2009 and standard for Food Safety and the HACCP System Based on MS 1480: 2007. They also refer to the standard MS 1500: 2009 and Manual Procedure (2005).

The GMP Standard MS 1514 provides guidance for determining halal food starting from its raw material to finished food served to consumers. One of the reasons for this practice is to help the industry to achieve a higher standard of food production that meets the requirements of food safety and consumer's needs. The GMP standard is used as the criteria for the inspection of buildings and facilities, including the water supply and storage, operation control practices and procedures, maintenance and sanitation, pest control and waste management, workers' hygiene, transportation and distribution.

The HACCP standard is a system to guarantee food safety by creating measures for pollution prevention for products and processes. It involves controlling three categories of pollution, namely the 1) physical contamination, such as glass or metal, 2) chemical pollution, such as toxin, and 3) biology toxins, such as bacteria. This pollution prevention occurs throughout the flow of the food process from the acquisition, reception of raw materials, processing, transmission and use of supervision and finished goods. The forms of control to prevent contamination of the physical, chemical and biological is also described in the standard MS 1500, MS 1514 and MS 1480.

With respect to storage, as stated in item 3.6 MS 1500, auditors have to make a report dan present it to the panel of halal certificate, if there are things that can raise a reasonable doubt and lead to element of doubtful (syubhah), such as storing the halal and non-halal foods in the same store or refrigerator. The panel will then decide the approval of the application. The Food Acts 1983 and Food Regulations 1985 should also be consulted during the inspection of the level of food security and cleanliness. Food Regulations 19 and 26 prescribe that additives, such as coloring, flavoring, preservatives, food conditioner, stabilizer, anti-oxidant and additional nutrients are allowed in any food product at a certain level. When a food product is found to contain additives at a level more than the one prescribed in the Food Acts and the Food Regulations, the food product is categorized as food injurious to health and application for halal certificate will not rejected.

This shows that the procedure for food cleanliness has been completely designed based on the standards and manual of processed food. It conforms to the criteria HL7 [Halal food must be clean and pure throughout the chain of its manufacturing process]. Meanwhile the procedures for food safety conform to criteria HL3 [Halal food must be able to preserve human's life and health, and any food that hinders this potential is considered haram]. 


\subsubsection{Sampling and Lab Analysis}

The sampling procedure is done by taking samples of food and sending them to a laboratory for analysis. This procedure only involves foods that are high risks and suspicion of fraud. There are also cases when JAKIM made analysis of samples from foods that are reported possibility of haram by the public (Sazly, 2008). Besides obtaining the cooperation of the Department of Chemistry, Halal Products Research Institute (IPPH) Universiti Putra Malaysia (UPM) has also helped to implement the analysis process on JAKIM halal food.

In general, the procedure of the laboratory analysis involves food that has high risk and doubtful element of haram only. It is consistent with criteria HL 4 [People have confidence without any doubt on the halalness of the food labelled as halal], and HL5 [Halal foods must not contain any parts of livestock that are haram or considered filthy].

\subsubsection{Determining Halal Slaughtering Process}

After the source of animal is identified from the category of consumable halal animal, another aspect to consider is to ensure that the animal is slaughtered according to the legal conditions of slaughtering. To ensure that the ingredients derived from animal that undergo halal slaughtering process, shariah auditor need to collaborate with the representatives of the Veterinary Services Department (VSD) to make inspection to the slaughter houses.

The inspection of the slaughter houses involves detailed examination from various angles. A legitimate slaughtering is a process that conforms to Islamic law of slaughtering. The conditions that need to be considered are the person who perform the slaughter, the equipment used, the method of slaughtering and the ethics of slaughtering as recorded in item 3.5.2.1 from a) to o). Further, the slaughter diagram in Figure 1 to Figure 4 in MS 1500 should also be referred. The purpose of a stunning method that seeks to weaken or make the animal faint, without causing any fatally is not encouraged. However, whenever this method is used, it is recommended that the requirements as specified in Appendix A in the standard MS 1500 is followed. The cleanliness of the slaughter house needs to be preserved and the guidelines of GMP standard MS 1514 need to be followed.

The procedure of slaughtering is clear and very detailed. A diagram illustrating the procedure is also displayed in the standard to provide proper understanding of the method to slaughter animals according to Islamic law. The reason for conducting the stunning method needs to be emphasised by JAKIM in order to ensure that it is not misused. Thus, this procedure conforms to criteria HL6 [Halal food must be slaughtered based on the Islamic law].

\subsubsection{Muslim's Participation in Food Processing}

Generally, the halal standard MS 1500: 2009 does not set any specific conditions in the involvement of Muslims in processing halal food. This condition is applied based on the statement in item 3.1.1 that states "The management shall appoint a chief executive officer who is a Muslim halal or establish a committee composed of Muslims who are responsible for ensuring the effective implementation of control systems halal". This statement is followed by item 3.1.2 which states that "The management should ensure that they receive training in the principles and applications of halal". Nevertheless, stringent conditions related to the involvement of Muslims in food processing have been described in the Manual of Procedure of Halal Certification in items 6.4 and 6.5 which are also used by JAKIM as their main reference.

This manual procedure clearly specifies the requirements of the involvement of Muslim employee. It helps to enhance any incomplete conditions in the standard MS 1500. This indirectly explains that the terms of engagement of Muslims in food processing is under the control JAKIM and this coincides with criteria HL8 [Halal food emphasizes elements of blessings. Therefore, Muslims must take part in the process of preparing the food].

\section{Conclusion}

Malaysian Standard MS 1500 prescribes the practical guidelines for food industry on the preparation and handling of halal food in Malaysia. The determination of Malaysia halal food is also implemented together with other related standards - MS 1480 and MS 1514 - on food safety and food hygiene. They are, to a certain extent, regarded as a guarantee that the food consumed is not only safe, but also halal. One should follow the model of halal standard with a holistic concept according to Islam. All components of the halal food must be from halal sources that have been handled, packed and stored properly in strict accordance to the Islamic syariah. Hence, this will ensure all ingredients of food and processes involved 'from farm to fork' are halal and permissible to all Muslims. The study reveals that the concept of halalan tayyiban has existed in the implementation of the procedure for the determination of halal food in Malaysia and it has been translated in the form of application referred to the reference standard. It has provided a platform towards a large segment of definition and 
understanding of the concept of halal food and tayyib in Islamic law. The findings also prove that the standards and guidelines used by JAKIM to determine halal food in Malaysia conform to the principles of Islamic law. Indirectly, it helps to restore Muslim consumers' confidence on JAKIM, with respect to the implementation of the halal standards and procedures. This study contributed to the need to maintain continuity and prosperity of the Muslim community in Malaysia.

\section{Acknowledgement}

This work was supported in part by Universiti Teknikal Malaysia Melaka, Malaysia.

\section{References}

Ahmad H. (2007). Community Participation and Empowerment: An Approach for JAKIM Halal Verification and Feedback Mechanism (Unpublished master's thesis). University Teknologi Mara, Malaysia.

al-Amidi, Sayf al-Din Abu al-Hassan 'Ali ibn Abi 'Ali ibn Muhammad. (1980). al-Ihkam fi Usul al-Ahkam (v. 1). Lubnan: Dar al-Kutub al-'Ilmiyyah.

al-Ghazzali, Abu Hamid Muhammad ibn Muhammad ibn Muhammad. (1993). al-Mustasfa min 'Ilm al-Usul (v. 1). Beirut: Dar al-Ihya' al-Turath al-'Arabi.

al-Ghazzali, Abu Hamid Muhammad ibn Muhammad ibn Muhammad. (n. d.). Ihya' 'Ulum al-Din (v. 2). Beirut: Dar al-Ma'rifah.

al-Qaradawi, Y. (1989). al-Halal wa al-Haram fi al-Islam. Cairo: al-Maktab al-Islami.

al-Qurtubi, Abi 'Abd Allah Muhammad ibn Ahmad al-Ansari. (n. d.). Tafsir al-Qurtubi al-Jami` li Ahkam al-Qur'an (v. 7). Beirut: Dar al-Sha'bi.

al-Sharbini, Shams al-Din Muhammad ibn al-Khatib. (n. d.). Mughni al-Muhtaj ila Ma'rifat Ma'ani Alfaz al-Minhaj (v. 4). Dimashq: Dar al-Fikr.

al-Shatibi, Abu Ishaq Ibrahim ibn Musa ibn Muhamad al-Lakmi. (1997). al-Muwafaqat fi Usul al-Sharíah. al-Shaykh 'Abd Allah Darraz (edit.), v. 1. Beirut: Dar al-Ma'rifah

al-Shawkani, Muhammad ibn 'Ali ibn Muhammad. (1999). Irshad al-Fuhul ila Tahqiq al-Haq min 'Ilm al-Usul. Muhammad Hassan Muhammad Hassan Isma'il al-Shafi'i (ed.), v. 1. Beirut: Dar al-Kutub al-'Ilmi.

al-Suyuti, Jalal al-Din 'Abd al-Rahman ibn Abu Bakr ibn Muhammad ibn Sabiq al-Din. (1990). al-Dar al-Manthur, v. 3. Beirut: Dar al-Kutub al-'Ilmiyyah.

al-Tabari, Abu Ja'far Muhammad ibn Jarir. (n. d.). Tafsir al-Tabari, v. 9. Mesir: Dar al-Ma'arif.

al-Zahrah, M. A. (1958). Usul al-Fiqh. Kaherah: Dar al-Fikr al- 'Arabi.

al-Zuhayli, W. (1969). al-Wasit fi Usul al-Fiqh. Dimasyq: al-Matba'ah al-'Ilmiyyah.

Cyril, G. (1989). The Concise Encyclopaedia of Islam. London: Stacey International.

Department of Islamic Development Malaysia (JAKIM). (2005). Manual Procedure of Halal Certification Malaysia. Kuala Lumpur: Percetakan Nasional Malaysia Berhad

Department of Islamic Development Malaysia JAKIM's Official Website. (2012). JAKIM. Retrieved February 10, 2012, from http://www.islam.gov.my/english/index.html.

Eliasi, J. R. (2002). Kosher and Halal: Religious Observances Affecting Dietry Intakes. Journal of the American Dietetic Association, 101(7), 911-913. http://dx.doi.org/10.1016/S0002-8223(02)90203-8

Harian Metro. (2008, January 29). Bebola Ikan Perut Babi.

Harian Metro. (2009, July 22). Tangani Sijil Halal Palsu.

Harian Metro. (2009, May 27). 50,000 Sijil Halal Palsu.

Harian Metro. (2010, February 4). Helah Keliru Pengguna.

Harian Metro. (2010, January 18). Tipu Berat, Logo Halal.

Harian Metro. (2010, January 4). Sijil Halal Ayam Cucuk.

Harian Metro. (2011, March 25). Kopi Campur Gelatin Babi.

Harian Metro. (2011, May 16). Protein Rambut Dalam Roti, Pau.

Harian, B. (2008, February 20). 3 Pembekal Ayam Tak Disembelih Disaman. 
Harian, B. (2009, July 11). HDC Tumpu Usaha Bangunkan PKS, Perkasa Hab Halal.

Harian, B. (2011, May 16). Dua Bahan Buat Kek. Roti Ada DNA Babi: JAKIM.

Harian, S. (2014, June 2). Cadbury: JAKIM Sahkan Bebas DNA Babi.

Ibn 'Ashur, M. al-T. (1984). Tafsir al-Tahrir wa al-Tanwir, v. 6. Tunisia: al-Dar al-Tunisi.

Ibn Hazm, A. M. (1983). al-Ihkam fi Usul al-Ahkam, v. 3. Beirut: Dar al-Afaq al-Jadidah.

Ibn Kathir, Abu al-Fida' Isma'il ibn 'Umar. (n. d.). Tafsir al-Qur'an al-Azim, v. 2, 3. Riyadh: Maktabah al-Riyad al-Hadithah.

Ibn Manzur, J. al-Din M. ibn M. al-A. (n. d.). Lisan al-'Arab, v. 4. Mesir: Dar al-Misriyyah li al-Ta'lif wa al-Tarjamah.

Jayyib, S. A. (1998). al-Qamus al-Fiqhi Lughatan wa Istilahan. Beirut: Dar al-Fikr.

Lokman, A. R. (2005). Syariah \& Malaysian Halal Certification System. Jurnal Penyelidikan Islam, 18, 15-36.

Malaysian Standard MS 1480:2007 Food Safety According to Hazard Analysis and Critical Control Point (HACCP) System (First Revision). Putrajaya: Department of Standards Malaysia.

Malaysian Standard MS 1500:2009 Makanan Halal: Pengeluaran, Penyediaan, Pengendalian dan Penyimpanan - Garis Panduan Umum (Semakan Kedua). Cyberjaya: Department of Standards Malaysia.

Malaysian Standard MS 1514:2009 Good Manufacturing Practice For Food (First Revision). Cyberjaya: Department of Standards Malaysia..

Md. Nor, A. G. et al. (Eds.) (2005). Kamus Dewan Edisi Ketiga. Kuala Lumpur: Dewan Bahasa dan Pustaka.

Mohammad, M. H. (1993). Islamic Dietry Concepts and Practices. Chicago: The Islamic Food and Nutrition Council of America (IFANCA)

Mohd, A. A. (2008). Shariah Auditor. JAKIM, Persiaran APEC Cyberjaya. Interview on 19 August 2008.

Muhammad, S. M. (1984). Nazariyat al-Ibahah 'Ind al-Usuliyyun wa al-Fuqaha'. Dar al-Nahdah al-'Arabiyyah.

Persatuan Pengguna Islam Malaysia. (2008). Pengguna Islam. Retrieved December 10, 2008, from http:///www.muslimconsumer.org.my

Riaz, M. N., \& Chaudry, M. M. (2003). Halal Food Production. USA: CRC Press. http://dx.doi.org/10.1201/9780203490082

Saifol, B. (2011, December 14-15). Isu dan Cabaran Semasa Dalam Pembangunan Industri Halal Di Malaysia. Paper presented at the Seminar Hukum Islam Semasa VII 2011.

Sazelin, A. (2012). Konsep Halalan Tayyiban Dari Perspektif Maqasid Al-Shariah dan Aplikasinya Dalam Prosedur Penentuan Makanan Halal Di Malaysia (Unpublished doctoral disertation). University of Malaya, Malaysia.

Sazelin, A., \& Ridzwan, A. (2011). Food Quality Standards in Developing Quality Human Capital: An Islamic Perspective. African Journal of Business Management, 5(31), 12242-12248. http://dx.doi.org/10.5897/ AJBM10.1692

Sazly, A. S. (2008). Food Technology Auditor JAKIM, Persiaran APEC Cyberjaya. Interview on 19 August 2008.

Sharifah Zannierah, S. M., Collin, M. H., \& Paul, W. B. (2012). Restaurant Managers' Perspectives on Halal Certification. Journal of Islamic Marketing, 3(1), 47-58. http://dx.doi.org/10.1108/17590831211206581

Undang-Undang Malaysia. (2007), Akta Makanan dan Peraturan-Peraturan. Kuala Lumpur: MDC Publishers Sdn. Bhd.

Utusan Malaysia. (2008, April 30). HDC Ambil Alih Tugas Pengurusan Sijil Halal JAKIM.

Utusan Malaysia. (2014, May 24). Coklat Cadbury Dikesan DNA.

Winai, D., \& Jongjit, A. (2006, July). Scientific Approach for Assuring Standard Regulation Compliance of Halal Food, Drug and Cosmetics Products. Paper presented at Seminar Kebangsaan Produk Halal Makanan dan Barang Gunaan Islam, Universiti Sains Malaysia, 13-14 July.

Zakiah, S., Amal Hayati, I., \& Nurul Himmah, K. (2014). Understanding the Development of Halal Food Standard: Suggestion for Future Research. International Journal of Social Science and Humanity, 4(6), 
482-486. http://dx.doi.org/10.7763/IJSSH.2014.V4.403

Zulkifli, H. (2007, August). Undang-Undang Produk Halal di Malaysia: Isu Penguatkuasaan dan Pendakwaan. Paper presented at the Konvensyen Undang-undang: Isu Penguatkuasaan dan Pendakwaan, Universiti Sains Islam Malaysia (USIM), 11-12 August.

\section{Copyrights}

Copyright for this article is retained by the author(s), with first publication rights granted to the journal.

This is an open-access article distributed under the terms and conditions of the Creative Commons Attribution license (http://creativecommons.org/licenses/by/3.0/). 